

\section{Funding Entrepreneurship and Innovation with Debt Capital: The Relevance of Capital Structure}

\section{George Obeng}

\section{Introduction}

Entrepreneurship has been the major source of economic engagement before the advent of formal education assuring students of factory and clerical employment. Businesses were financed from personal equity or debt as the circumstances may warrant and owners accepted unlimited liability. Today unemployment is the lot of young men (Kuschel, Lepeley, Espinosa, and Gutiérrez, 2017) graduating from educational institutions, and creating social dislocation. Re-orienting entrepreneurship for economic eminence faces the challenge of personal equity funding (Block, Colombo, Cumming and Vismara, 2018; Fischer, Malycha, and Schafmann, 2019). Initiating a business with debt funds has to contend with capital structure and the threat of financial distress.

Before industrial revolution for mass production that required formal training for engagement, men were born into family vocations, trade and professions offering them immediate jobs. The existing family business structures required of no capital investment that the young man has to struggle for. The young ones were engaged by their parents, relatives and acquaintances for training and absorption into the family business. The tools and implements of production were simple, easier to learn and be trained to make use of them, with little automation.

As population surged on, demand for goods and services of different forms and nature as well as for different purposes prompted social change and economic taste. Business entities formed by group of persons with public financial support emerged in mass production during the industrial revolution. People were trained for skills and competencies in formal school setups to take up jobs in industries.

Today, schools just supply labor and are not matched by the required demand from industry, creating unemployment in many societies and countries like Ghana. Knowledge acquired in schools should be translated into the creation of small businesses as has been before. However, the challenge in most cases, is lack of personal equity (Block, Colombo, Cumming and Vismara, 2018; Fischer, Malycha, and Schafmann, 2019). External equity to push innovation and entrepreneurial initiative is not an easy venture and debt capital becomes an obvious alternative, but risk of capital structure is a threat.

The fear of financial distress is obscuring the opportunities of initiating entrepreneurial engagements using debt capital to finance entrepreneurship. The relevance of capital structure in finance has been considered in different ways in theory. The understanding and knowledge of capital structure and its interpretations as well as application in different environments, circumstances and by different investors has not received in-depth attention.

Capital structure explains how a firm secures and engages long term funds, equity and debt, with different terms and conditions of reward and repayment (Pratheepkanth, (2011). Debt and equity should be at equilibrium to ensure optimum performance and derive some benefits from tax savings over financial distress (Modigliani \& Miller 1958). There is possible departure from the capital structure theory of optimality to focus on optional choice of capital structure. The choice is at the discretion of the investor, contingent on the prevailing financial systems, financial needs in the life cycle of the firm, social settings and culture from where the decision is made (Obeng, 2019). Modigliani and Miller (MM) (1958) observed the irrelevancy of capital structure postulating that a firm cannot change the value of its outstanding securities by changing its capital structure. The value of the firm remains same under different capital structures.

The understanding and knowledge of capital structure relevance in application may differ in interpretation for different environments, situations and by different investors and their disposition. Capital structure understood on the basis of innovation, accepting risk to ensure change of hopeless situation to seek opportunities will zero-in capital structure as threat and make it irrelevant. Risk avoidance stance of any investor zero-in innovation and accept relevance of capital structure. Investors may understand and know that business is financed from personal equity and debt making the capital structure. However, the returns, reward and their risk may have different meaning and understanding to an investor dependant on the prevailing necessity and circumstances. Investors who understand the financial system and financial needs of the business and that reward or benefit goes with risk always turn around risk for opportunity and capital structure cannot deter them.

Investment is about risk taking in response to a challenge, creating an opportunity to turn a hopeless situation to vibrancy. The risk of using debt capital to take up any opportunity with innovative ideas, summon available resources efficiently. Investors in this case understand the financial system and needs of the business and its environment. They do away with their selfinterest of charging their compensation as expense against income; rather they see their interest as appropriation of profit with other stakeholders for success and benefit to society to reduce unemployment. Such entrepreneurial initiative sees capital structure risk as irrelevant in their investment drive. On the other hand, ordinary entrepreneurs may lack innovation and understanding of the financial system and needs of the business. They may be inefficient in mobilizing resources and see their interest as charge against income. They recognize capital structure and its risk as relevant and avoid liability in a way to protect selfish-interest and cripple employment. 


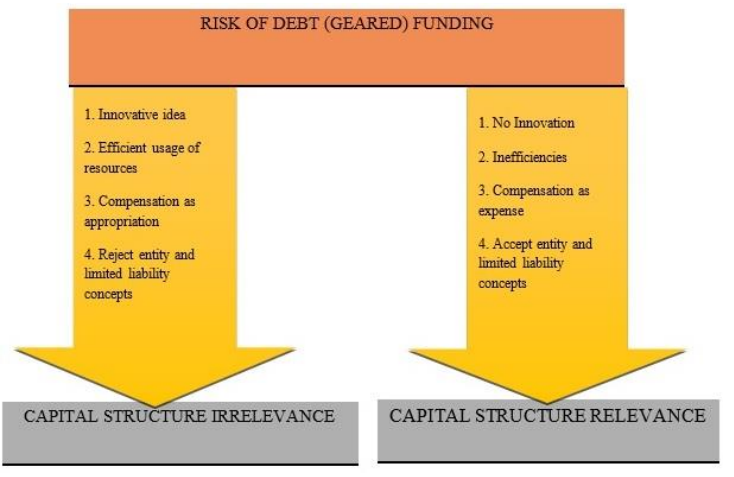

Figure 1. The Risk/Vibrancy Model

Source: Composed by Author, 2020

\section{Entrepreneurship and Unemployment}

Unemployment has been a problem the world is battling with. A lot of young men graduate from schools with high hopes of securing befitting jobs to use the skills acquired from their educational training. However, such opportunities are disillusioned. According to the International Labour Organisation, an estimated of 1.4 billion workers were in states of vulnerable employment in 2017, and an additional 35 million were expected to join them by 2019 . Northern Africa has the highest jobless percentage in the world, $11.5 \%$ in 2018. With Sub-Saharan Africa, the rate is expected to stick to levels observed since 2017 at $7.2 \%$. Almost half of all workers - more than 900 million - are in vulnerable forms of employment.

There is some attempt to use entrepreneurship to address the gloomy picture of unemployment among the youth (Gupta, Beninger and Ganesh, 2015; Doherty, Haugh and Lyon, 2014; Nziku and Struthers, 2018; Bongani and Chinaza, 2018). The G20, of the global political leaders, in their summit in Turkey had the intention of increasing employment through an initiative dubbed G20 Youth Entrepreneurs Alliance (YEA). It is observed that entrepreneurs play a vital role in job creation and providing opportunities to young people (Maria Pinelli, 2015; Alinejad, Balaguer, Hendrickson, 2015; Felix Moses Edoho, and Edoho, 2015). Entrepreneurial development should provide an avenue for job creation to absorb job seekers and for economic growth (Saha, 2016; Kuschel, Lepeley, Espinosa, and Gutiérrez, 2017; Felix Moses Edoho, and Edoho, 2015). To use entrepreneurship as a means of solving the unemployment menace, two strategically approaches can be considered. Entrepreneurship that is of large scale approach which is solely manned or owned by group of persons and entrepreneurship that can be absorbed more in a way as social enterprises (Gupta, Beninger and Ganesh,_2015; Doherty, Haugh and Lyon, 2014; Nega and Schneider, 2014). The other approach is on small scale operated by one person to make a living. In any of these approaches, the entrepreneurship can be capital intensive with some automation or labor intensive absorbing more hands (Gupta, Beninger and Ganesh, 2015; Doherty, Haugh and Lyon, 2014; Nega and Schneider, 2014; John and Storr, 2018). The adoption of any of the strategies may depend on the socio-economic environment and the available traditional industries as well as cultures (John and Storr, 2018).

In industries with long multiple processes of production requiring capital investment and some automation, one person or group of individual entrepreneurs may pull resources together in an initiative to engage more hands. This is symbolic in the agroprocessing businesses of converting raw agricultural produce of fruits and vegetables into juice as well as designing and fashion in the textile industry and catering. Cooperatives can be formed to handle the different aspects of the production chain and they can be supported. Members of the cooperatives can be given training and they may be specialized in different aspects of the production processes.

Individual entrepreneurs as self-employed in their small ways, in agriculture, trade and cottage industries can offer some services and produce dairy products for immediate communities and environments requiring simple implements. Such businesses should consider the means and needs of society to ensure its sustainability (Saha, 2016). The educational system of the country should factor these traditional industries and practices into the educational systems, particularly technical and vocational education to equip majority of the people. Through entrepreneurial initiatives and innovations, these industries can turn around efficiently to absorb greater numbers of the unemployed of society.

\section{Understanding Capital Structure to Attract Funding}

This section discusses capital structure relevance on the valuation of the firm. Capital structure should be a contingency concept, dependent on innovation. Innovation should drive efficiency to zero-in capital structure and make it irrelevant.

Classical financial theories and models demonstrate the relevance of capital structure. It is defined severally as the ratio of equity to debt capital, a mix that maximizes a firm's return on capital, and maximizes its value (Pratheepkanth, 2011). Return on capital may vary from time to time to influence the value of the firm to obtain an expected optimal capital structure for the best value of the firm. The absence of capital structure optimality exposes the firm to risk, a consideration of cost of capital, return on capital, tax savings, cost of bankruptcy, agency cost and information asymmetry (Modigliani \& Miller 1958). The theory postulate returns to be higher than weighted average cost of the capital structure, thereby increases the value of the firm.

Tax savings occasioned by interest deductibility improve returns, subsequently increasing the value of the firm (Candela, retrieved 2/10/19), as debt increases more tax gains, which is expected to increase the value of the firm. However, as the debt increases the chances of bankruptcy and cost threatens the security, sustenance and stability of the firm emanates from possible default in paying the debt as they fall due. As the cost of capital increases with highering in capital demand, bankruptcy cost rises due to default risk. Business firms trade off debt and equity to have an optimal mix of capital structure to maximize the value of the firm (Candela, retrieved 2/10/19). 
There is also information asymmetry (Vy Le, Thi Bich, 2017), which explains how information is controlled by management against making it public. This has cost implications, because investors get their information through deduction of management behaviour, which can be negative in making investment decisions. Any wrong signal can affect the firm negatively in capital structure decisions. Management dilemma in employing capital to work for the benefit of their principals or for their own interest, has been of concern and be a cost to the firm. It is often postulated that, managers consider their interest before the owners. In this case, capital structure is considered as another means to control agency behavior by requiring them the provision of relevant information ( $\mathrm{Vy} \mathrm{Le}$, Thi Bich, 2017).

These factors give cognizance to the relevance of capital structure. The relevance of capital structure is a tutelage of market imperfection, where risk is prominent and these steps are worthy for consideration if risk is to be avoided or controlled in the investment process. Return on investment and its optimization is dependent on how costs emanating from these factors are managed. With this understanding, securing funds for new venture initiatives in imperfect market environment, that would be disillusioned. However, entrepreneurial initiative should be seen in a different light and perspective as an innovation with the drive to turn around a hopeless situation into vibrancy (Reyad, Musleh Al-Sartawi, Badawi and Hamdan, 2019) to the benefit of society.

Entrepreneurship as innovation is not anchoring heuristic or confirmation bias, that does not accept and appreciate opportunities coming along with challenges. Innovation sees and unveils opportunities in challenges, delimits and quarantine risks, set objectives achievable within perfect market orientation (Reyad, Musleh Al-Sartawi, Badawi and Hamdan, 2019). The demand of investors for higher rewards, security of investment on capital assets and contractual relationship for the payment of reward and repayment of capital are not ordinarily or something out of place. It is a call on management to accept their responsibility to be efficient in handling and putting to good use the resources made available to them (Wilson and Zhenyu Wu, Chowdhury, and Maung, 2013).

Management is under obligation to honor the demands of the owners for their rewards and security of their assets. Management should have their ultimate goal efficiency in the internal information and communication systems in making finance and investment decisions (Maung and Chowdhury, 2014). In this dispensation any risk that comes the way of entrepreneur presents him an opportunity, requiring innovation to handle each case on its merits efficiently, and turn around hopeless situation into vibrancy. The entrepreneur who understands the financial systems and needs of the business and the environment it is operating sees capital structure optimality as irrelevant with relevancy going with optionality. This to an entrepreneur with innovation, who combines production resources efficiently for success.

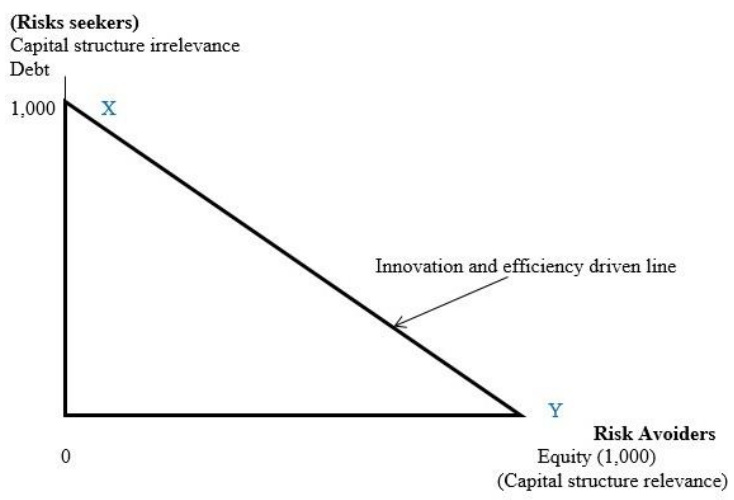

Figure 2. Entrepreneurial-Liability-Possibility Model: Turning Hopeless Situation to Vibrancy

Source: Composed by Authors, 2020

\section{The Entrepreneurial-Liability-Possibility Model}

The indicated Entrepreneurial-LiabilityPossibility Model depicts entrepreneurial initiative, which is innovation and efficiency driven (line XY). Entrepreneurs with innovation are risk seekers and employ available resources efficiently to achieve their objectives with no reference to capital structure as risk to hold them aback. They understand the financial systems, the financial needs of the business and its operational environment. They can efficiently use $100 \%$ debt at X to achieve success. Risk avoiders may not understand their systems, needs and environment, see capital structure as relevant and may prefer $100 \%$ equity at $\mathrm{Y}$. The more the innovation and efficiency bring on board by entrepreneurs, the more irrelevant capital structure becomes. In the absence of innovation and efficiency, the more capital structure becomes relevant. Entrepreneurs accepts liability to others with an inner possibility drive to achieve and appropriate success to benefit stakeholders. They see their reward as appropriation not as expense to others.

\section{Classification of Entrepreneurs for Capital Attraction}

In an attempt to classify entrepreneurship, it is important to understand that it takes different meaning from separate authors. According to the Macmillan dictionary, "An entrepreneur is someone who uses money to start businesses and make business deals". Peter Kilby (1971) described the entrepreneur as "Heffalump"; a character with different particulars.

An entrepreneur is an independent minded person who accepts the challenge to lead a hopeless situation, marshalling available resources and applying innovative skills, to give meaning to life and optimize the lots of society (Obeng, up). Entrepreneurship may be classified essentially according to its engagement as to either self-employed in own private business or in employment with another person. It may be classified according to the different levels of engagement of entrepreneurial capacity in any economic activity (John and Storr, 2018; Teixeira, Casteleiro, Rodrigues and Guerra, 2018). 
A person may depend on others for engagement to make ends meet in a routine task under instructions. The person contributes little or no other resources apart from labor, no managerial or leadership skills, take no risk to effect change. In this case, we may say he is at the lower level of employing his entrepreneurial capacity.

Other persons are independent minded, may be engaged by others or have their own businesses, contributing resources, bring in managerial and leadership skills, take risk in decision making and bring change to bear on society. The level of combination of the behavioral variables of dependency, resources, leadership skills, take risk to effect change to benefit society implies the level of innovation and the order of entrepreneurship. Such consideration and innovation is not limited by capital structure.

Wickham (2004) gave some classifications according to the venture and the strategic approach taken. $\mathrm{He}$ gave classification of approach as entrepreneurs themselves or their ventures. Entrepreneurship is classified as nascent (start-up) entrepreneurs and singular entrepreneurs. Singular entrepreneur is also made of opportunist, who maximizes profit from short-term deal; and craftsmen who make living in selling their trade or products. Opportunist may be growth-oriented aiming to maximize their potentials or be independent-oriented, who work for themselves. Craft may be income oriented or expansion oriented. Craft may also have skill classification as; traditional, technological or professional skills. Other classifications are Cantillon, industry maker, administrative entrepreneur and small business. Further classification is on the ratio of expected return and payoff. There is large payoff with many participants; small payoff with few participants and large payoff with few participants. Clearly defining entrepreneurship distinctively to attract the right sources of funding is absurd.

It does not matter the type and classification. Entrepreneurship needs funding either from equity or debt. An entrepreneur may choose any structure of capital according to his understanding and interpretation of the prevailing circumstances in the immediate environment and the innovation he is bringing on board. The entrepreneur would have to take risk in making the choice and the propensity to risk and his adventurous innovation should dictate the relevancy or otherwise of his capital structure.

One major classification of entrepreneurship innovation ventures that, what has been overlooked in literature is the compensation and benefits due to entrepreneurs and how they are treated in the books. In this regard, entrepreneurs can be classified as; entrepreneurs with benefits charge as expense against the business income and entrepreneurs with benefits seen as appropriation of income or profit among stakeholders. In this regard, the entrepreneurs (either employed or owner of business) who charge their compensation as expense against the business income may see themselves strictly as agents of the business and should be paid compensation as determined or agreed upon. The compensation is charged whether the business made enough profits or not and whether the business is solvent and liquid or not. Such entrepreneurs may lack innovation. They can borrow to pay themselves and satisfy their interest to the detriment of the business and other stakeholders.

Entrepreneurs with compensation as an appropriation of income consider themselves as agent and owner of the business even if employed. Their objective is bringing innovation to bear on the business activities to succeed and solve social problems and share in the glory and profits. They employ available resources efficiently to better the lot of stakeholders and the general society. They don't make distinction of funds made available to the business and make capital structure irrelevant to achieve their goal. This classification gears towards the quest of entrepreneurs to be independent, owner-agent in employing and contributing resources of a venture. They bring managerial and leadership skills to bear on the venture. They take risk and accept liability to reward stakeholders as conventional practice to be honored, bring change in an innovative manner to create wealth for growth to the benefit of stakeholders and society at large. Funding in such innovation limits capital structure factors and their risk, therefore capital structure is seen as irrelevant. This encourages the use of any fund as contracted fund or debt capital in whatever structure in an efficient manner to achieve results.

\section{Funding Entrepreneurships}

This section looks at the problem of securing funding for entrepreneurial initiative and innovation. According to Alinejad, Balaguer, Hendrickson, (2015) innovative entrepreneurial firms denote a congruence of three business initiatives; innovative firms, young and high growth firms and small and medium enterprises (SMEs). In this case, any personal attempt by any individual or group of persons that initiate business firm to offer any product for commercial use can be prescribed as innovative entrepreneurial firm. We go further to say that, the innovative firm should denote efficiency in an effort to turn a hopeless situation into vibrancy for the good of society. Funding entrepreneurship and innovation is seen as a big challenge (Alinejad, Balaguer, and Hendrickson, 2015) in an attempt to motivate and encourage people unemployed to engage themselves privately (Nziku and Struthers, 2018). The funding problem may stem from the initiator or promoter of a new business, expansionary work, implementing a research outcome of innovation for new idea or efficiency in providing a product, not having personal equity funding or unable to secure external funding from equity or debt capital. The problem of funding such innovations disappoints young persons who are unemployed or may not want to be employed by other persons, but be on their own. The problem of funding ventures deprives society of economic growth (Nziku and Struthers, 2018), creates unemployment (Kuschel, Lepeley, Espinosa, and Gutiérrez, 2017) and deprives governments of tax revenues to secure the welfare of the general citizenry.

Funding entrepreneurial innovation may take different forms, from separate sources and at different stages of the business development with some form of conditions to be fulfilled (Carr, 2019). At the start-up level, funding may come from the personal equity of the entrepreneur and family and friends' equity. Start-ups can also secure funding from external sources of equity and debt. If entrepreneur in start-up is a craft with 
interest to earn income for a living, personal equity and that from family may be enough. The issue is not about innovation to expand or come out with anything new, therefore may not accept external funding. They may want to avoid dilution and have to control a family interest and cultures. To their understanding, capital structure is relevant in terms of dilution and not about risk of bankruptcy. Further, such entrepreneurs will go to take debt, because they are owner-agent entrepreneurs appropriating income for their compensation and not the expense. Therefore, they can pay their debt even against their interest. The entrepreneur with innovation to achieve efficiency and go for expansion and growth, in any case, may go for external funding such as debt (Wilson and Zhenyu Wu, Chowdhury, and Maung, 2013) or equity and other innovative sources of funds. The owner-agent entrepreneurs appropriating income for their compensation and not as expense take their innovation as change agent. Then, they expect to change a hopeless situation to vibrancy and may not want to lose control through capitalisation, therefore may go for debt capital.

The issue of failure is not anticipated, but the attainment of and focus on the objective of creating wealth and growth. In this case, capital structure relevancy is not in the decision equation. With management-agency position where compensation is an expense and managers seeking their interest, decision for external funding may consider capital structure. They reject liability to others, but protect their interest in limiting or avoiding risk of financial distress. This can be averted if the management ignore this expense treatment and behave as if their expense is appropriation to secure efficiency and performance, which will render capital structure irrelevant in their understanding and interpretation. A research work in Australia on financing innovative entrepreneurship by Alinejad et'al (2015) established that, debt finance is not an issue and there is $90 \%$ success in securing debt finance, however, request for equity and venture capital are on the lower side.

We can classify the funding in perspectives of debt or equity, investment goal, investment approach, and investment target (Block, Colombo, Cumming and Vismara, 2018). We may have founders' equity, family and friends, government grants and loans, angel investors, incubators, venture capitalists, banks, bootstrapping, crowd funding, external equity financing and debt capital. Equity financing is the ownership interest in the enterprise, which is from the business operator or families and friends who do not have contractual obligation to receive interest and repayment of principal. It is also funds received from selling shares to the public, who become shareholders in the firm. Shareholders receive dividend as their returns and is received when the directors declare it at the firm's Annual General Meeting. Shareholders have the risk of not receiving any dividend when not declared and also lose their funds when the firm is liquidated on grounds of inability to pay their debt when due. Shareholders in this case may consider capital structure as relevant when management as agent have their interest at stake and consider their compensation as expense against income. Management then may not be innovative enough to ensure efficiency to turn any hopeless situation to vibrancy. They reject liability to others, but protect their interest and capital structure relevant to them. When agency is innovative, efficiency and performance are prime (Wilson and Zhenyu Wu, Chowdhury, and Maung, 2013). They see their compensation as appropriation and interpret capital structure as irrelevant, accept liability to capital providers in securing additional funding and reject strict adherence to entity and limited liability concepts.

Debt financing is funds borrowed by the firm for which it is obliged to pay interest on regularly and repay the principal at maturity, else bankruptcy proceedings may be filed against the firm. Venture capital is special form of equity to finance costly, highrisk, high-return technology-based innovative firms attractable at any stage of the development of the firm (Alinejad et'al, 2015). Its acquisition is also dependent on dilution and control of the owner-agent interest, management-agency and their treatment of compensation.

Accelerators (and incubators) are described as organizations, which aim to help start-ups with mentorship, advice and network access for growth. Business Angel (BA) financing have traditionally been a source of financing young innovative firms, that find it difficult to access bank or debt finance. Angel networks are networks of Business Angels with focus of investing together in early-stage high growth ventures. The group provides equity and offer management support and network access with higher amounts of financing. Crowd-funding covers diverse forms of fundraising, using the Internet. Groups of people contribute funds to support a particular goal in different forms including; reward-based, donation-based, lending-based, and investment-based (equity) crowd-funding. Rewardbased crowd-funding project takes some customized product or service, ego-boosting or the offering of symbolic objects that display support for a project. Donation-based crowd-funding may comprise individuals or non-governmental organizations raising money with the motivation to donate for charitable giving and social image. Lending-based crowd-funding including peer-to-peer lending are motivated to invest as lenders to receive fixed interest rates for their loans. With equity-based crowd-funding, entrepreneurs make an open call to sell a specified amount of equity or bond-like shares in a company on the Internet. Corporate venture capital (CVC) is investments by large, established firms into start-ups or growth firms. Large firms in protecting their interest and develop in growth do not acquire ventures and absorb them. They take a minority equity stake in innovative young firms, make them independent, and help them further develop their promising technologies and markets. The CVC is interested in strategic goals of having access to new technology, new markets or customer segments.

Families with large firms establish family offices as intermediaries to manage their wealth (Block, et al, 2018). They avoid direct ownership and hold on to the family office, where they unload their interest to a professional wealth management to reduce conflicts, which may lead to fail investment for efficiency. They invest in growth ventures and have become important players in the market for entrepreneurial finance as equity investors (Block et al, 2018).

Governmental Venture Capital $(G V C)$ fund is a funding source to reduce the financial gap for entrepreneurial initiatives and to pursue investments, that will yield social payoffs and positive externalities to 
the society. The Government objectives differences result in the heterogeneity in the types of firms available to receive GVCs investment funds and their efficiency in using the funds. The heterogeneity of government objectives and its intentions come out with some categories of; direct public funds, hybrid private-public funds, and funds-of-funds. Direct public funds invest through government-supported Venture Capital schemes to facilitate the development of a Venture Capital industry within a region or industry. Co-investments with private investors, an innovation is initiated to cater for areas lacking skills and crowing-out issues. Government support may take the form of funds-offunds to invest in other investment funds rather than investing directly into companies (Block et al, 2018).

Other funds as documented by Block et al (2018) include Intellectual Property Fund (IP), a form of patents where innovative firms or investors see monetarism in their Intellectual Property and use the funds generated to grow their venture. It is not equity nor debt, but intellectual assets of a company. It backs debt funding to give firms the opportunity to use the economic value of their IP to obtain loans from banks or other financial institutions. Mini-bonds are public bonds issued in special SME bond segments used as a financing instrument by SMEs.

Social venture capital fund is a seed-funding to social enterprise (Doherty, et al 2014), that works for profit. The funding can come in both debt and equity, with the goal to achieve a reasonable financial return and at the same time delivering social impact. University-managed or university-based funds supports ideas or research findings from university faculty, staff, and alumni. Technology innovation developed in labs is not close to the market. Therefore, universities need to fund research internally to get the technology ready to a development partner from the private sector. Venture debt lenders or funds are specialized financial institutions bringing together venture capital and traditional debt sources of funding. They provide loans to start-ups that do not require securities or positive cash flows from start-ups.

The emerging and proliferation of funding sources may be a direct response to social, economic and cultural changes that manifest in a world of dynamism with challenges of different business structures. This makes entrepreneurship complex in classification and categorization to attract the right source of funding for the fear of loss of investment assets and their reward. This has called for new legislation and stiffer regulations and control that may work against businesses (Felix Moses Edoho, and Edoho, 2015). Consequently, return to investors becomes unattractive and they may also bring innovations to develop other means to engage their funds. In the absence of internal flow of funds and collateral to secure funding, businesses are challenged to be innovative and open up to provide investors with the right information. Entrepreneurs and agency should be transparent and accept liability in dealing with investors or financiers. Investors may require business efficiency with innovative agency in an effort to turn a hopeless situation into vibrancy for the good of society and zero-in the risk of capital structure.

\section{Methodology}

Research Design

The investigation made use of the descriptive design and the survey research strategy for data collection. The survey strategy is appropriate for study with broad setting to help achieve economy (Saunders et al 2007).

\section{Estimation Technique}

The study used the logit model to establish the relationship between the dependent variable, capital structure, as to how an investor will choose equity or debt to finance entrepreneurial innovation or initiative as well as the independent variables of; understanding (perception of capital structure), reality of capital structure to an investor, consideration of capital structure in investment decision, knowledge in capital structure, advice and guidance on capital structure, changes in capital structure and how they influence investment decision. Generally, the logit model is formulated as follows:

$$
L_{i}=\ln \left(\frac{P_{i}}{1-P_{i}}\right)=\beta_{1}+\beta_{2} X_{i}+\mu_{i}
$$

To estimate (1), we need, apart from $X_{i}$, the values of the regressand, or logit, $L_{i}$. the dependent variable, capital choice is such that $P_{i}=1$ if an individual prefers bond and $P_{i}=0$ if otherwise.

\section{Limitations}

The major limitation of this study is data collection from the potential investors, who may come from different backgrounds and cultures. Cultural differences can affect the responses and defile the technical position of investment decision. These may influence the outcome of the study and therefore call for further studies.

\section{Empirical Model Specification}

The empirical model formulated by the study to be estimated is as follows:

$\operatorname{Prob}($ CapChoice $=1 \mid X i)=b_{0}+b_{1}$ Und $_{i}+$ $b_{2} U n d 2_{i}+b_{3} K w l 1_{i}+b_{4} K w l 2_{i}+b_{5} K w l 3_{i}+$ $b 6 K w l 4 i+e_{i}$

Where;

CapChoice - is capital structure choice which is how an investor will choose equity or debt to finance entrepreneurial innovation or initiative (takes the value one if an individual prefers bond and zero if otherwise).

Undl- is the variable representing understanding (perception of capital structure). Und2 - is reality of capital structure to an investor. 
$K w l 1$ - is the knowledge variable that represents how an investor considers capital structure in investment decision.

$K w l 2$ - is knowledge of capital structure influencing investment decision.

$K w l 3$ - is advice and guidance on capital structure influence investment decision.

Kwl4 - is how changes in capital structure affect investment decision

Three empirical models were considered to run the logit to measure how capital structure influences investment decision or test the relevance of capital structure or otherwise in investment decision. Model 1 runs the logit test on influence of understanding (perception) and reality of capital structure on investment decision. Model 2 measures consideration of capital structure, knowledge of capital structure, advice and change in capital structure influencing investment decision. Model 3 measures both understanding and knowledge of capital structure influencing the investment decision.

Table 1: Logit Regression for Understanding and Knowledge of Capital Structure

\begin{tabular}{|c|c|c|c|}
\hline Variables & Model 1 & Model 2 & Model 3 \\
\hline UND 1 & $1.109^{*}$ & & 0.913 \\
& $(0.470)$ & & $(0.587)$ \\
\hline UND 2 & $-1.118^{* *}$ & & $-1.293 * *$ \\
& $(0.277)$ & & $(0.333)$ \\
\hline KWL 1 & & -1.003 & -0.900 \\
& & $(0.566)$ & $(0.710)$ \\
\hline KWL 2 & & 0.293 & 0.694 \\
& & $(0.540)$ & $(0.617)$ \\
\hline KWL 3 & & 0.342 & 0.128 \\
& & $(0.407)$ & $(0.447)$ \\
\hline KWL 4 & & 0.607 & 0.743 \\
& & $(0.410)$ & $(0.482)$ \\
\hline Constant & 0.769 & 0.290 & 0.420 \\
& & & $(0.785)$ \\
\hline Model Parameter & & $0.646)$ & \\
\hline Obs. & 219 & 219 & 219 \\
\hline Log likelihood & -132.169 & -132.893 & -114.422 \\
\hline LR Chi-squared & 19.67 & 5.91 & 22.08 \\
\hline Prob > Chi-squared & 0.000 & 0.2062 & 0.001 \\
\hline Pseudo R-squared & 0.069 & 0.022 & 0.088 \\
\hline Overall Classification & $68.04 \%$ & $65.09 \%$ & $69.74 \%$ \\
Rate & & & \\
\hline
\end{tabular}

Note: Standard Errors are in the bracket

From the empirical model UND $1=$ Perception of capital structure in investment decision, UND $2=$ Reality of understanding of capital structure, KWL $1=$ Consideration of capital structure influencing investment decision, $K W L 2=$ Knowledge in capital structure influencing investment decision, $K W L 3=$ Advice and guidance on capital structure influencing investment decision, $K W L 4=$ Changes in capital structure affecting investment decision.

Significance Level: $* p<0.05 * * p<0.01$

\section{Results and Discussion}

Stata 14.0 was used to run the logit models 1,2 and 3 on the influence of choice of capital made of equity and bond. The test results for equity and bond in qualitative and quantitative terms came up with same results. To safe space, the report on bond is presented here as representing both bond and equity. The log likelihood test gave p-values of $-132.169,-132.893$ and 114.422 for models 1,2 , and 3 . These attest the fact that, the models fit significantly better for the study to make relevant predictions.

Potential investors' perception of capital structure was seen to be statistically significant to influence their choice of investment assets and the reality of capital structure was also seen to be statistically significant to influence a person's choice of capital. The likelihood that a person would choose a particular investment asset over the other according to his understanding or perception is greater than the other four variables measuring knowledge of capital structure, advice and guidance on capital structure, as well as changes in capital structure by a factor of 1.109 at 5 percent significant level. The reality of capital structure influencing investors in their choice of investment was also statistically significant by a factor of -1.118 and a chi square of 0.000 at significance level of 1 percent. This relationship reveals that, the likelihood that a person's understanding, perception and reality of capital structure in making investment decision has more predictable returns.

Model 2 on four measurements of knowledge as consideration of capital structure, knowledge of capital structure, advice and counselling on capital structure, and change in capital structure influencing investment decision was not statistically significant with a chi-square value of 0.2062. For model 3, measuring both understanding and knowledge of capital structure were found to be a significant predictor of an individual's choice of capital. Potential investors were found to have a greater likelihood of choosing investment assets (bond and shares), when they have knowledge and understand of capital structure according to their interpretation than just consideration of capital structure, knowledge in capital structure, advice and guidance on capital structure, changes in capital structure by a factor of 1.293 , at 1 percent level of significance with chi-square value of 0.001 . This result points to the fact that capital structure perception and reality to the investor have a stronger preference and influence on choice of investment assets when compared to knowledge, advice and guidance, and changes in capital structure. It can be deduced from this result that perception and reality as seen by the investor have a stronger preference for capital choice with more predictable returns over the other variables of consideration of capital structure, knowledge in capital structure, advice and guidance on capital structure, changes in capital structure, which have less predictable returns.

\section{Conclusion and Recommendations}

Securing funds for the development of entrepreneurship and innovation in a way to engage the youth coming out from educational institution and to address the unemployment menace have been a challenge. People with entrepreneurial innovative ideas may lack personal equity capital and support from family as well as friends. Employing debt capital also has the flaw of financial distress. How capital structure can influence funding entrepreneurial funding was the subject of this study. Potential investors' understanding or perception and reality of capital structure influencing 
investment decisions were tested. Moreover, four measures of knowledge namely; consideration of capital structure, knowledge of capital structure, advice and guidance on capital structure as well as changes in capital structure influencing investment decision were also tested. The study reveals that, there is a strong relationship between an individual's perception and reality on capital structure as well as investment decision with significant factors of 1.109 for perception and 1.118 for reality and chi square of 0.000 .

The investors understanding of financial system and needs of the business in accordance with their socio-economic disposition, culture and environment they find themselves give them varying options to make a choice. Entrepreneurs with innovative ideas are risk seekers determined to use all debt capital structure, be efficient in employing available resources to bring change by turning hopeless situations into vibrant economic piece and space. They ensure performance to benefit all stakeholders and they see their compensation as appropriation of profits and not as an expense against profits. Such individuals see capital structure not being risky nor threat to their success. Investors who prefer equity are risk avoiders and understand the relevancy of capital structure as risky and threat to their success. Such investors are critical about where and how their resources are put to use. They shirk their responsibility to others and always protect their interest against others by accepting the concepts of entity and limited liability when they have recklessly managed the affairs of the business.

The test that measured consideration of capital structure, knowledge of capital structure, advice and counselling on capital structure and change in capital structure influencing investment decision was seen not to be significant with a chi-square factor of 0.2062 . With this revelation, we posit that investors who rely on consideration of knowledge from the market place and advice of others lack understanding of the financial system in making investment choice. They are influenced by psychological distortion of herding, deficient in innovative ideas to change any hopeless situation into vibrancy. Application of the available resources may not signal efficiency and the market environment may be evidenced by imperfections with little success to count on. Such entrepreneurs factor their compensation as an expense against income, seeking their own interest. Such entrepreneurs don't have fair understanding of capital structure as to its relevance or irrelevance and are conscious of their investment in order not to risk what they have and depend on others for direction.

It is important to note that, having knowledge about capital structure in itself does not significantly affect or influence investment decisions. Understanding of capital structure in terms of perception and the reality to the investor can influence investment decision. It can be deduced that, capital structure as a factor on its own cannot influence investment decision. Knowledge of capital structure can be fruitful only when an investor understands the issues at stake in accordance to his/her situation and prevailing circumstances as demonstrated by model 3 . This produced a significant factor of -1.293 and a chi-square of 0.001 . The relevancy of capital structure in investment decision therefore becomes optional in accordance with the objectives the investor seeks to achieve and not just the dictate of theory. Using debt to finance entrepreneurial innovation and initiative is feasible and may not pose any threat to an entrepreneur with innovative ideas, who understands the financial system and needs of the business and accepts liability to financiers without the excuse of entity and limited liability concepts.

Entrepreneurship is not adequately defined with specified features and characteristics to help identify the appropriate sources of funding. It is important that entrepreneurship with innovation is clearly positioned with distinct objective and features. The concepts of entity and limited liability in owner-agent controlled enterprises should be properly addressed and possibly distinguished from the public limited liability company with large shareholding. Entrepreneurship with innovation should establish owner-agent responsibility and liability to financiers. Owner-agent responsibility in small enterprises should have a second look on limitation of liability. Their compensation should not be seen as expense against profit, but as an appropriation of income among all stakeholders with none exonerated from liability when there is failure. Entrepreneurship with innovation should have stated objectives and oriented research, coming out with new products of superior potency, an improvement to an existing product or a new technology to improve efficiency as well as effectiveness in the production process. There should be consideration for separate legislation for such entrepreneurial initiatives to enforce owner-agent responsibility and liability to assure investors of the security of their investment in small innovative enterprises.

\section{References}

Alinejad, M., Balaguer, A., and Hendrickson, L (2015). Financing innovative Entrepreneurship; Australian Government, Department of Industry, Innovation and Science, Research paper $8 / 2015$

Block, J. H., Colombo, M. G., Cumming, D. J. et al. (2018). Small Bus Econ 50:239 https://doi.org/10.1007/s11187-016-9826-6

Bongani T. G., Chinaza, U. (2018). Entrepreneurship: solution to unemployment and development in rural communities, Journal of Entrepreneurship Education, Vol: 21 Issue: 1S, ISSN: 10988394; Online ISSN: 1528-2651).

Carr, P. (2019). Technology Innovation and Entrepreneurship; establishing connections with potential investors (Google Scholar, retrieved: 10/10/19).

Doherty, B., Haugh, H. and Lyon, F. (2014), "Social enterprises as hybrid organizations: A review and research agenda", International Journal of Management Reviews, Vol. 16 No. 4, 417-436. 
Felix Moses Edoho, P. and Edoho, F. (2015). "Entrepreneurship and socioeconomic development: Catalyzing African transformation in the 21st century", African Journal of Economic and Management Studies, Vol. $6 \quad$ No. 2, 127-147. https://doi.org/10.1108/AJEMS-03-2013-0030

Fischer C., Malycha C. P., Schafmann, E. (2019).The Influence of Intrinsic Motivation and Synergistic Extrinsic Motivators on Creativity and Innovation; Front. Psychol., 04 February 2019 https://doi.org/10.3389/fpsyg.2019.00137

Global Finance Global news and insight for corporuate financial professionals; Unemployment Rates around the World 2018; (Retrieved 29/9/19)

Global Youth Unemployment is on the Rise Again; From ILO http://goo.gl/6muI2R (Retrieved 29/9/19)

Government Department of Industry, Innovation and Science; Research Paper 8/15

Gupta, S., Beninger, S. and Ganesh, J. (2015). "A hybrid approach to innovation by social enterprises: lessons from Africa", Social Enterprise Journal, Vol. 11 No. 1, 89-112. https://doi.org/10.1108/SEJ-04-2014-0023

John, A. Storr, V. (2018), "Kirznerian and Schumpeterian entrepreneurship in Trinidad and Tobago", Journal of Enterprising Communities: People and Places in the Global Economy, Vol. 12 No. 5, 582-610. http://doi.org/10.1108/JEC-05 2018-0034

Kilby, P. (1971). Hunting the Heffalump; University of Illinois, at Urbana-Champaign, Academy for Entrepreneurial Leadership; Historical Research Reference in Entrepreneurship. Posted 4th November, 2009.

Kuschel, K., Lepeley, M., Espinosa, F. and Gutiérrez, S. (2017). "Funding challenges of Latin American women start-up founders in the technology industry", Cross Cultural \& Strategic Management, Vol. 24 No. 2, 310-331. https://doi.org/10.1108/CCSM-03-2016-0072

Lmencandela, boundless finance; capital structure conservations (retrieved: $2 / 10 / 19$ )

Maung, M. and Chowdhury, H.R. (2014). "Is there a right time for corporate investment?", Studies in Economics and Finance, Vol. 31 No. 2, pp. 223-243, available at: https://doi.org/10.1108/SEF-08-2013-0112 [Link], [Google Scholar] [Infotrieve]

Modigliani, F. and Miller, M.H. (1958). "The cost of capital, corporation finance and the theory of investment", American Economic Review, 48(3), 261-297.
Nega, B and Schneider, G. (2014). "Social entrepreneurship, microfinance, and economic development in Africa", Journal of Economic Issues, Vol. 48 No. 2, pp. 367-376.

Nziku, D. and Struthers, J. (2018). "Female entrepreneurship in Africa: Strength of weak ties in mitigating principal-agent problems", Journal of Small Business and Enterprise Development, Vol. 25 No. 3, 349-367. https://doi.org/10.1108/JSBED-032017-0115.

Obeng, G. (2019). Sociological and Cultural Influence on Choice of Capital in Emerging Markets; International Journal of Economics and Management Studies 6 (9) 56-65: DOI; 10,14445/2393125.IJEMS=V619P105

Obeng, G. (Press). Contractual obligation of claims, a factor influencing investors' choice of capital.

Pinelli, M. (2015). Can entrepreneurship solve the youth unemployment crisis? (Retrieved 29/9/19).

Pratheepkanth, P., (2011). Capital Structure and Financial Performance Evidence from Selected Business Companies in Colombo Stock Exchange, Sri Lanka; Journal of Arts, Science and Commerce.

Reyad, S., Musleh Al-Sartawi, A., Badawi, S. and Hamdan, A. (2019). "Do entrepreneurial skills affect entrepreneurship attitudes in accounting education?", Higher Education, Skills and Work-Based Learning, Vol. 9 No. 4, 739-757. https://doi.org/10.1108/HESWBL-01-20190013

Teixeira, S., Casteleiro, C., Rodrigues, R. and Guerra, M. (2018). "Entrepreneuria intentions and entrepreneurship in European countries", International Journal of Innovation Science, Vol. $10 \quad$ No. $1, \quad 22-42$. https://doi.org/10.1108/IJIS-07 2017-0062

Vy Le T. P., Thi Bich N. P. (2017). Capital structure and firm performance: empirical evidence from a developing country; Research in International Business and Finance 42. July; DOI: 10.1016/i.ribaf.2017.07.012

Wickham, A. P. (2004). Strategic Entrepreneurship, Financial Times, Business \& Economics, Boston. Prentice Hall.

Wilson and Zhenyu Wu, C., H. Chowdhury, R. and Maung, M. (2013)."Corporate entrepreneurship and debt financing: evidence from the GCC countries", International Journal of Managerial Finance, Vol. 9 No. 4, 294-313. https://doi.org/10.1108/IJMF-11-2012-0124 